\title{
Sociobiology
}

RESEARCH ARTICLE - ANTS

\section{Aphaenogaster ichnusa Santschi, 1925, bona species, and Redescription of Aphaenogaster subterranea (Latreille, 1798) (Hymenoptera, Formicidae)}

\author{
C GALKOWSKI ${ }^{1}$, C AUBERT ${ }^{1,2}$, R BLATRIX $^{1,2}$ \\ 1 - Antarea (www.antarea.fr), Association for the Study and Mapping of the Ants of France \\ 2 - CEFE, CNRS, University of Montpellier, University Paul Valéry Montpellier 3, EPHE, IRD, Montpellier, France
}

\section{Article History}

Edited by

Kleber Del-Claro, UFU, Brazil

Received

Initial acceptance

Final acceptance

Publication date

01 August 2018

06 December 2018

29 January 2019

14 November 2019

\section{Keywords}

Ant taxonomy, COI, DNA barcode, Western

Palearctic, Corsica, Sardinia.

\section{Corresponding author}

Christophe Galkowski

104 route de Mounic, 33160

Saint-Aubin-de-Médoc, France.

E-Mail:chris.gal@wanadoo.fr

\begin{abstract}
Morphological and molecular investigation conducted in France and the Tyrrhenian islands reveal that Aphaenogaster subterranea is composed of two distinct species. We propose to raise A. subterranea var. ichnusa Santschi, 1925, described from Sardinia, to the species status, A. ichnusa Santschi, 1925 stat. nov. This species differs from $A$. subterranea by having shorter propodeal spines and a less sculptured cuticle. Phylogenetic reconstruction using the mitochondrial marker $\mathrm{COI}$ shows that the two species form well separated clades, with a genetic distance (K2p) of $9.8 \%$. In the studied area, the two species are parapatric, $A$. ichnusa occurring in Sardinia, Corsica and the Mediterranean area of continental France, and $A$. subterranea occurring north of this area. We propose a redescription of both species and designation of a neotype for $A$. subterranea.
\end{abstract}

\section{Introduction}

Aphaenogaster subterranea (Latreille, 1798) is considered a common species in Europe. The type specimens were collected around Brive-la-Gaillarde, Corrèze, France. The identification of specimens from France was not considered problematic. However, specimens from Corsica and the Mediterranean coast show morphological characters that differ noticeably from those of specimens from the rest of France (including Brive-la-Gaillarde). These characters are (i) shorter and more triangular propodeal spines, (ii) a smoother cuticle, and (iii) a body color globally lighter. This combination of characters led to identification errors: specimens with propodeal spines particularly reduced are labeled as Aphaenogaster pallida (Nylander, 1849) in the André collection at the Muséum National d'Histoire Naturelle of Paris (MNHN). These specimens, used as reference, led numerous authors to mention A. pallida from Southern France and Corsica in a range of publications (André, 1883; De Gaulle, 1908; Emery, 1908; Bernard, 1968, 1983; Casevitz-
Weulersse, 1990). Those characters, albeit stable within the Mediterranean population, were most often considered irrelevant in systematics. Indeed, lighter individuals occur naturally in all populations and the sculpture of the cuticle varies to some extent within most species of the genus Aphaenogaster Mayr, 1853. The differences between Mediterranean and non-Mediterranean specimens could correspond to mere intraspecific variability, or could result from particular environmental conditions under Mediterranean climate (ants tend to have a lighter color when developing at higher temperature).

Aphaenogaster subterranea has a broad distribution, from Western Europe to Asia Minor and Caucasus, throughout which it has a rather homogeneous morphology. Thus, the ancient authors described few varieties or sub-species, although they were quite prolific with this respect in other genera. Interestingly, Santschi (1925) described the taxon ichnusa as a mere variety of $A$. subterranea. The type specimen is from Sorgono, Sardinia. According to Santschi, the variety ichnusa differ from the typical subterranea by its yellow- 
brownish color, by the seventh article of the funiculus more elongated and by the propodeal spines weaker. In his revision of the palearctic Aphaenogaster, Finzi (1930) did not find any difference in the size of the funiculus segments between the specimens of ichnusa and of subterranea he had access to. He only noticed, again, the small and triangular propodeal spines. Baroni Urbani (1971), in his catalog of the ants of Italy, only reported the existence of the variety ichnusa, considered as endemic to Sardinia.

The type of A. subterranea var. ichnusa, of which high quality pictures can be viewed online thanks to the AntWeb project (available from http://www.antweb.org. Accessed 4 July 2018. Specimen CASENT0913132), shows the same combination of morphological characters as specimens from Corsica and the Mediterranean coast of France. We present a morphological and molecular analysis of specimens of $A$. subterranea collected in Sardinia, Corsica and continental France, showing that the taxon ichnusa should be considered as a valid species, distinct from $A$. subterranea sensu stricto. We propose hereafter the redescription of $A$. ichnusa stat. nov. and of $A$. subterranea, and the designation of a neotype for $A$. subterranea.

\section{Material and methods}

\section{Morphometrics}

The following characters were measured (all measures are in $\mathrm{mm}$ ):

HL: maximum length of head, measured along a median line from vertex to anterior margin of clypeus.

HW: maximum width of head, including the eyes.

SL: maximum length of scape. The condylar bulb is excluded from the measurement..

ED: maximum diameter of the eye.

ML: maximum length of mesosoma (alitrunk).

MW: maximum width of mesosoma, measured on pronotum. PSL: length of propodeal spine, measured from the center of the propodeal spiracle to the tip of the spine.

PW: maximum width of petiole.

PL: maximum length of petiole.

PPW: maximum width of post-petiole.

PPL: maximum length of post-petiole.

From these measurements, four ratios were computed: cephalic index $\left(\mathrm{HW}^{*} 100 / \mathrm{HL}\right)$, scape index (SL*100/HL), mesosoma index (ML*100/MW), spine index (PSL*100/ HL). Using the maximum length of head as denominator, we intent to reduce the effect of inter-individual size variation.

\section{Mitochondrial DNA analysis}

New DNA sequences for part of the gene coding for the cytochrome c oxidase subunit I (COI, $658 \mathrm{bp}$ ) were obtained either within the framework of the International Barcode of Life project (iBOL) or at the Center for Evolutionary and Functional Ecology (CEFE) in Montpellier,
France. In the latter case, each specimen was used entirely for DNA extraction, whereas in the former case, only one leg was used and vouchers were stored at the CEFE. After DNA extraction, the COI fragments were amplified through polymerase chain reaction (PCR) using the primer pairs LepF1: 5'-ATTCAACCAATCATAAAGATAT-3' and LepR1: 5'-TAAACTTCTGGATGTCCAAAAA-3' (Hebert etal., 2004). Sanger dideoxy sequencing of the unpurified PCR amplicons was performed in both direction using the same primers as those used for the initial amplification. Sequences were edited using CodonCode Aligner (CodonCode Corporation, Dedham, MA, USA), and contigs were built from forward and reverse sequences generated for each gene. Conflicting base calls were coded using the ambiguity code. Sequences were aligned with Muscle (Edgar, 2004). Alignments were inspected visually and edited manually using Mesquite v. 3.31 (Maddison and Maddison, 2017) when they could be improved. Genetic distances were estimated in Mesquite using the Kimura 2-parameter model (K2p).

A partition scheme was defined with PartitionFinder (Lanfear et al., 2016) for each phylogenetic analysis, using the Akaike Information Criteria for nucleotide substitution model selection. Prior data blocks were defined by codon position. Phylogenetic reconstructions were performed using Bayesian inference with MrBayes v. 3.2.6 (Ronquist et al., 2012). Two analyses of four chains were run for 1000000 generations, sampling trees every 500 generations with $25 \%$ burn-in samples discarded for each run. The phylogenetic tree was rooted using Messor structor (Latreille) as outgroup.

\section{Results}

Redescription of Aphaenogaster subterranea (Latreille, 1798) and designation of a neotype

The type specimen of $A$. subterranea designated by Latreille could not be found in the collection of the National Museum of Natural History (MNHN) in Paris, France, and we consider it is lost. In order to fix a neotype and paraneotypes, we collected worker specimens from one nest at Brive, terra typica of the species. The neotype is deposited at MNHN. Nine workers from the same nest, designated as paraneotypes, are deposited at MNHN, from which a new neotype could easily be designated in case of loss or destruction of the neotype. Ten workers of this same nest have also been deposited at the Senckenberg Museum für Naturkunde of Görlitz, Germany.

\section{Material examined for morphometrics:}

Brive 45.169N 1.500E, $210 \mathrm{~m}, 02-\mathrm{VII}-2008$, forest edge. Neotype of Aphaenogaster subterranea.

Fumel44.494N 0.960E, 341 m, 11-VIII-2002, leaflitter. Sauveterre de Guyenne 44.707N 0.087W, 20-IV-1998, forest edge. Saint Sever 43.783N 0.526W, 17-VII-2004, leaf litter. Mont de Marsan 43.894N 0.497W, 18-VII-2004, urban parc. Saint Aubin de Médoc 44.926N 0.730W, 12-VII-2002, garden. 
Pauillac 45.217N 0.765W, 31-VIII-2001, garden. Hourtin 45.224N 1.167W, 12-III-2002, leaf litter. Duravel 44.517N 1.083E, 12-VIII-2004, leaf litter. Mauroux 44.452N 1.043E, 29-X-2017, leaf litter. Châteauroux 46.825N 1.697E, VI1995, park. Berzy le Sec, 30-IV-2017 leg Colindre. Bethisy Saint Martin, 15-IX-2016 leg Colindre. Aigueblanche, 15VIII-2016 leg Colindre. Puy Mary, 11-VI-2015 leg Lebas.

\section{Redescription of the worker (Table 1, Fig 1)}

Head brown, of the same color as the rest of the body, longer that wide, widening from mandibles to occiput. Eyes rather small, c. 1/6 of head length, located lateraly at midlength between occiput and clypeus. Scapes long, overreaching the occipital margin distinctly, very slightly arched, their diameter increasing from base to apex. Funicular segments $c$. 1.5 times longer than wide, antennal club weakly pronounced, of four segments. Clypeus almost smooth, with a few weak longitudinal carinae, anteriorly emarginate. Frontal carinae short, frontal lobes narrow. Head weakly sculptured, with a few striae extending from frontal carinae and around the eyes. Space above antennal fossae weakly reticulate. The sculpture of the cuticule vanish towards the occiput, which is entirely smooth.

Table 1: Morphometric characteristics of Aphaenogaster subterranea and $A$. ichnusa. Mean $\pm \mathrm{sd}$ (min-max). Characters in bold are the most discriminant.

\begin{tabular}{|c|c|c|}
\hline & $\begin{array}{l}\text { Aphaenogaster } \\
\text { subterranea }(\mathrm{n}=30)\end{array}$ & $\begin{array}{l}\text { Aphaenogaster } \\
\text { ichnusa }(\mathrm{n}=30)\end{array}$ \\
\hline $\mathrm{HL}(\mathrm{mm})$ & $\begin{array}{l}1.056 \pm 0.066 \\
(0.935-1.131)\end{array}$ & $\begin{array}{l}1.047 \pm 0.116 \\
(0.918-1.156)\end{array}$ \\
\hline HW (mm) & $\begin{array}{l}0.962 \pm 0.070 \\
(0.816-1.029)\end{array}$ & $\begin{array}{l}0.951 \pm 0.112 \\
(0.816-1.088)\end{array}$ \\
\hline $\mathrm{SL}(\mathrm{mm})$ & $\begin{array}{l}1.021 \pm 0.044 \\
(0.918-1.054)\end{array}$ & $\begin{array}{l}0.991 \pm 0.068 \\
(0.918-1.071)\end{array}$ \\
\hline $\mathrm{ED}(\mathrm{mm})$ & $\begin{array}{l}0.185 \pm 0.017 \\
(0.153-0.204)\end{array}$ & $\begin{array}{l}0.176 \pm 0.020 \\
(0.161-0.212)\end{array}$ \\
\hline MW (mm) & $\begin{array}{l}0.572 \pm 0.039 \\
(0.510-0.612)\end{array}$ & $\begin{array}{l}0.575 \pm 0.064 \\
(0.493-0.680)\end{array}$ \\
\hline $\mathrm{ML}(\mathrm{mm})$ & $\begin{array}{l}1.390 \pm 0.076 \\
(1.207-1.462)\end{array}$ & $\begin{array}{l}1.352 \pm 0.140 \\
(1.190-1.530)\end{array}$ \\
\hline PSL (mm) & $\begin{array}{l}0.193 \pm 0.026 \\
(0.153-0.217)\end{array}$ & $\begin{array}{l}0.155 \pm 0.033 \\
(0.110-0.204)\end{array}$ \\
\hline PL (mm) & $\begin{array}{l}0.402 \pm 0.024 \\
(0.357-0.425)\end{array}$ & $\begin{array}{l}0.405 \pm 0.037 \\
(0.357-0.459)\end{array}$ \\
\hline $\mathrm{PW}(\mathrm{mm})$ & $\begin{array}{l}0.209 \pm 0.018 \\
(0.170-0.230)\end{array}$ & $\begin{array}{l}0.205 \pm 0.018 \\
(0.187-0.238)\end{array}$ \\
\hline PPL (mm) & $\begin{array}{l}0.287 \pm 0.021 \\
(0.247-0.323)\end{array}$ & $\begin{array}{l}0.265 \pm 0.025 \\
(0.221-0.306)\end{array}$ \\
\hline PPW (mm) & $\begin{array}{l}0.271 \pm 0.021 \\
(0.221-0.289)\end{array}$ & $\begin{array}{l}0.249 \pm 0.023 \\
(0.221-0.281)\end{array}$ \\
\hline $\begin{array}{l}\text { Cephalic index } \\
\mathrm{HW}^{*} 100 / \mathrm{HL}\end{array}$ & $\begin{array}{l}91.1 \pm 2.9 \\
(86.2-94.7)\end{array}$ & $\begin{array}{l}90.8 \pm 1.1 \\
(89.3-92.9)\end{array}$ \\
\hline $\begin{array}{l}\text { Scape index } \\
\text { SL*100/HL }\end{array}$ & $\begin{array}{l}96.8 \pm 3.1 \\
(93.3-103.6)\end{array}$ & $\begin{array}{l}95.1 \pm 5.0 \\
(85.7-100.9)\end{array}$ \\
\hline $\begin{array}{l}\text { Mesosoma index } \\
\text { ML*100/MW }\end{array}$ & $\begin{array}{l}243.4 \pm 7.0 \\
(236.1-260.0)\end{array}$ & $\begin{array}{l}235.2 \pm 7.6 \\
(222.9-247.2)\end{array}$ \\
\hline $\begin{array}{l}\text { Spine index } \\
\text { PSL*100/HL }\end{array}$ & $\begin{array}{l}18.2 \pm 1.6 \\
(15.3-20.2)\end{array}$ & $\begin{array}{l}14.7 \pm 2.0 \\
(12.1-19.0)\end{array}$ \\
\hline
\end{tabular}

Mandibles strong, rounded, with a few longitudinal striae, masticatory margin armed with $c$. 4 relatively strong apical teeth followed by c. 4 basal denticles more or less distinct. The whole head is covered by long, semi-erect, setae. Many semi-erect to semi-decumbent setae on the scape.
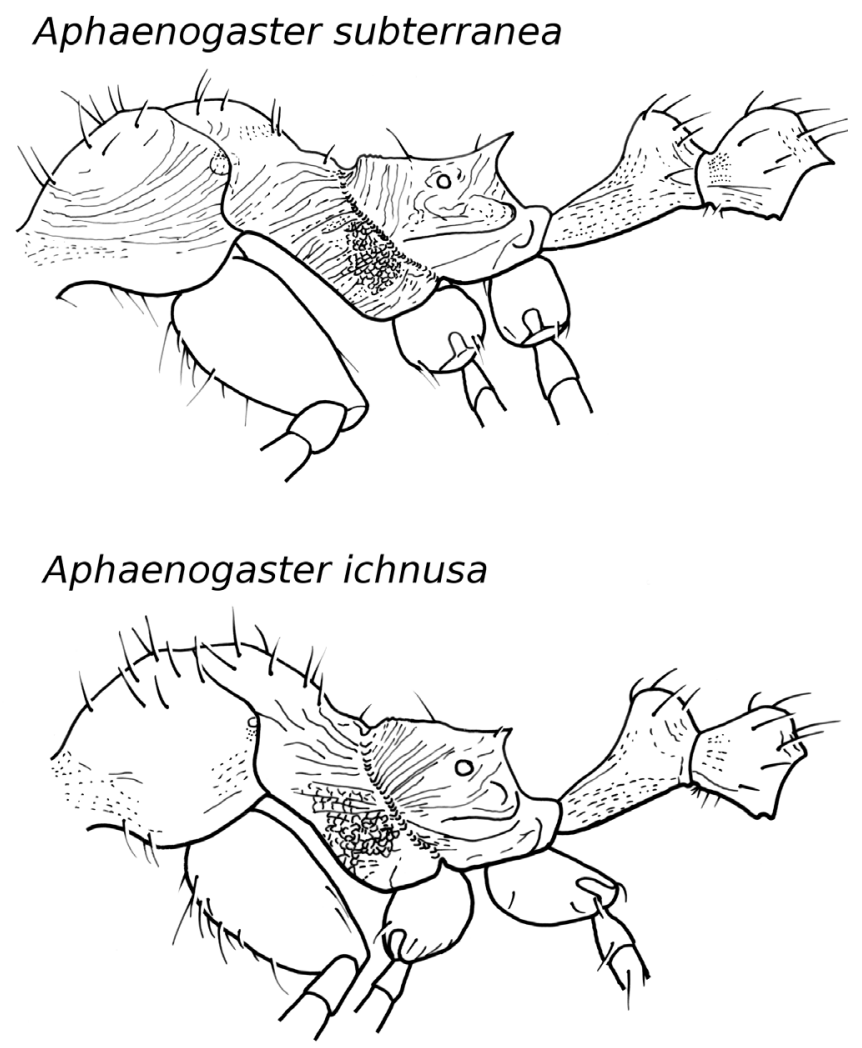

Fig 1. Illustrations of Aphaenogaster subterranea and A. ichnusa stat. nov. showing the reduced propodeal spines and the less sculptured pronotum for the latter.

Mesosoma evenly brown, light brown or dark brown, with long erect setae, more numerous on pronotum and mesonotum. Promesonotum very rounded, separated from propodeum by a guttershaped groove. Propodeal spines clearly distinct, pointed shaped, oriented at $c .45^{\circ}$, of a length almost equal to the distance between their tips. Cuticle weakly sculptured: sides of pronotum with weak longitudinal striae, space between wrinkles smooth or slightly irregular, summit of pronotum almost smooth. Mesonotum a bit more sculptured, with sometimes a few transversal striae at the summit. Mesopleuron et propodeum much more sculptured, with marked longitudinal ridges separated by a dense reticulation mainly visible on the lower part of the mesopleuron, summit of propodeum with transversal ridges. Space between propodeal spines almost smooth with a few fine transversal striae.

Petiole and post-petiole brown. Petiole with a long anterior peduncle, summit of node rounded, anterior and posterior faces convex. Post-petiole rounded. Cuticule smooth on nodes, slightly sculptured on the peduncle of the petiole and on the lower lateral parts of petiole and post-petiole. Nodes of petiole and post-petiole with a few long semi-erect 
setae directed backwards.

Gaster smooth and shiny, of the same color as mesosoma or sometimes slightly darker in the lighter individuals. All gaster segments with long erect or semi-erect setae, and with sparse pubescence made of thin and appressed hairs.

Appendices long, light brown, with many decumbent or semi-decumbent setae, and a few semi-erect setae on the interior border of femurs and tibias.

Distribution in France and Tyrrhenian islands: Fig 2.

Redescription of Aphaenogaster ichnusa Santschi 1925, stat. nov.

We did not examine the type specimen directly but we viewed the high quality pictures of it accessible online thanks to the AntWeb project (available from http://www.antweb. org. Accessed 4 July 2018. Specimen CASENT0913132)

\section{Material examined for morphometrics:}

Agay $43.427 \mathrm{~N}$ 6.846E, $83 \mathrm{~m}, 14-\mathrm{VII}-2008$, cracks in rock. Saint Raphael 43.443N 6.849E, 15-VII-2008, leaf litter. Ile de Port Cros, 24-X-2015 leg Séchet. Montpellier, 01-VI2014 leg Blatrix. Banyuls 42.461N 3.089E, 19-IV-2006, leaf litter. Fitou 42.873N 2.988E, 23-VI-2010. Argelès sur Mer, 29-III-2017 leg Lebas.

Corsica:

Piana 42.242N 8.654E, 18-VII-2011, under a stone. Col de Bavella 41.795N 9.226E, 23-VII-2009, forest. Tizzano, 14-IV-2017 leg Colindre. Bonifacio 41.405N. 9.123E, 14VII-2013, under stone in forest.

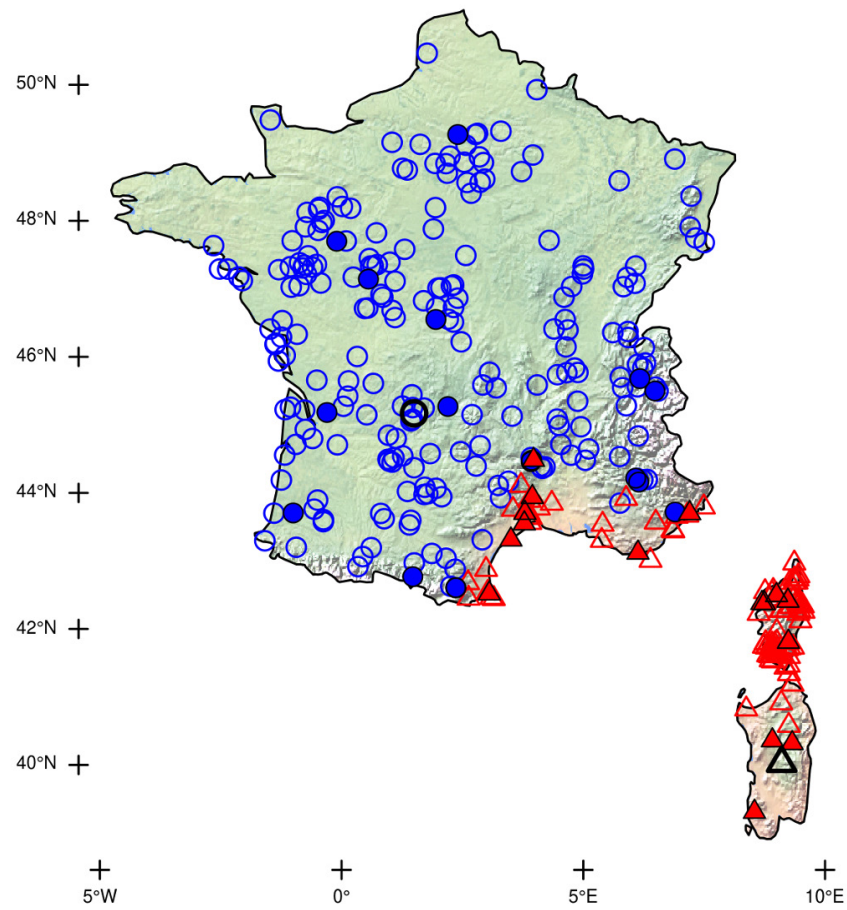

Fig 2. Distribution map of Aphaenogaster subterranea and A. ichnusa stat. nov. in Corsica, Sardinia and continental France. Blue circles: A. subterranea; red triangles: A. ichnusa; large black symbols: type localities for the two species; filled symbols: morphology and mitochondrial DNA (COI) were investigated; empty symbols: only morphology was investigated.

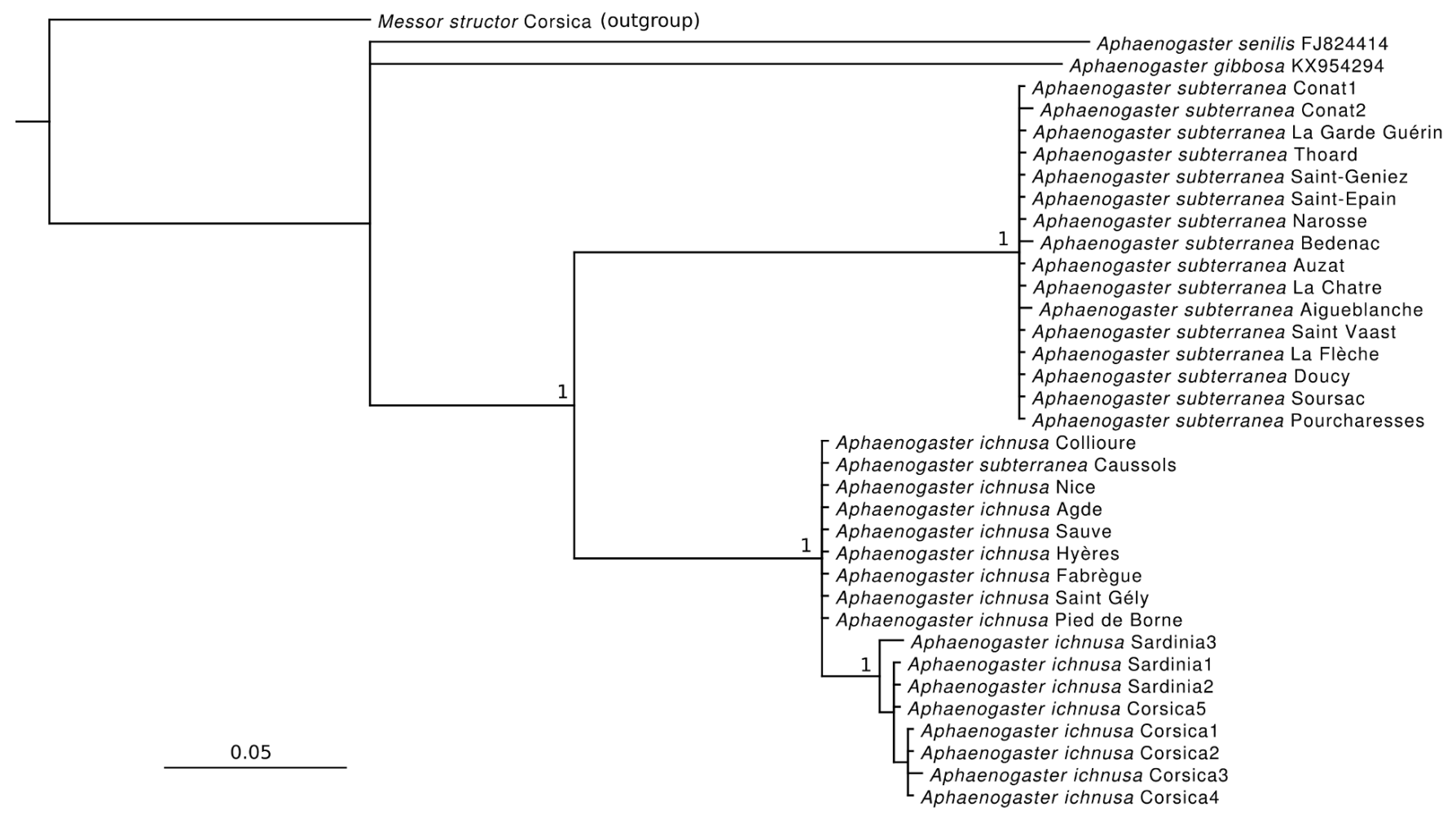

Fig 3. Phylogenetic reconstruction of specimens of Aphaenogaster subterranea and A. ichnusa stat. nov. in Corsica, Sardinia and continental France, based on a Bayesian approach using the cytochrome c oxidase subunit I gene (COI). Posterior probabilities above 0.90 are indicated. 
Sardinia:

Olbia 41.186N 9.328E, 24-VII-2014, leaf litter. Tempio Pausania 40.911N 9.094E, parc. Bolotana 04-V-2011 leg Verdinelli. Buddusò 01-VI-2017 leg Verdinelli. Nuoro 01VI-2016 leg Verdinelli.

Redescription of the worker (Table 1, Fig 1)

Whole body brown yellow, some nests contain darker individuals. Head characters as for A. subterranea, but sculpture of cuticle finer, carinae on clypeus almost indistinguishable, and smooth space on the occiput larger. Continental specimens may be more sculptured as those from Corsica and Sardinia. Cuticular pattern on mesosoma as for A. subterranea, but weaker, summit of pronotum and mesonotum and space between propodeal spines entirely smooth. Propodeal spines short, triangular, sometimes reduced to mere carinated angles in small individuals. The setae have the same distribution as for A. subterranea. Petiole, gaster and appendices as for $A$. subterranea, setae on tibias finer and more decumbent.

Distribution in France and Tyrrhenian islands: Fig 2.

\section{Mitochondrial DNA analysis}

For this study, 34 new COI sequences were generated ( 22 by iBOL and 12 by the CEFE), with GenBank accession numbers MH138330 to MH138350, MH138398 and MH630453 to MH630464. Sequences are also publicly available on the dataset "DS-ASUB - Aphaenogaster subterranea and Aphaenogaster ichnusa" of the BOLD Barcode of Life Data Systems (Doi: dx.doi.org/10.5883/DSASUB). The dataset included 658 characters. The two species form two well supported clades (Fig 3) with a K2p genetic distance of $9.8 \%$. The average intraspecific genetic distance is $0.06 \%$ for $A$. subterranea and $0.7 \%$ for $A$. ichnusa. For $A$. ichnusa, the genetic distance between mainland France and the Tyrrhenian islands (Corsica and Sardinia) is $1.2 \%$. Only one specimen, from Caussols, shows a disagreement between morphology and COI (Fig 3). This specimen was collected on a meridional plateau at $>1000 \mathrm{~m}$ asl, which hosts cold tolerant insect communities although it is close to the Mediterranean cost. Introgression between the two species is likely to explain this disagreement.

\section{Conclusion}

Schulz (1994) defined the A. subterranea species group which was considered to contain a dozen species. Our study, along with others in progress (see Salata and Borowiec, 2018), reveal that this group is more diversified that previously thought.

Although our study focuses on France, which represents only a small part of the distribution range of the A. subterranea group, the two species here show roughly parapatric distributions that seem driven by climate. Aphaenogaster ichnusa seems to be restricted to areas under the influence of the Mediterranean climate whereas $A$. subterranea is found in more temperate environments. Although the Tyrrhenian islands are located in the Mediterranean region, both $A$. subterranea and $A$. ichnusa are reported from Sicily (Schifani and Alicata, 2018), and only A. ichnusa in Corsica and Sardinia. In Sicily, A. subterranea is found above $1200 \mathrm{~m}$ asl and A. ichnusa at lower altitudes (Schifani and Alicata, 2018), confirming opposite climate preferences between the two species. Our sampling includes a few sites on the transition zone between Mediterranean and temperate climates where the two species are detected a few $\mathrm{km}$ apart. Nevertheless, the two genetic clades are clearly distinct, suggesting efficient reproductive isolation although the two species may occur in sympatry in certain regions.

\section{Acknowledgements}

We thank Thierry Noel (University of Montpellier), Thibaud Decaëns and the members of the Groupe Naturaliste de l'Université de Montpellier (GNUM) for their help in processing samples, Paul Hebert (University of Guelph) for providing a privileged access to $\mathrm{iBOL}$ sequencing facility, and Marie-Pierre Dubois and the Service des Marqueurs Génétiques en Ecologie (CEFE) for providing facilities for molecular biology bench work. Many ant specimens were obtained through the AntArea project (www.antarea.fr). This research was funded by grants from the Fond de Solidarité et de Développement des Initiatives Etudiantes (FSDIE) of the University of Montpellier and from the Office de l'Environnement de la Corse (OEC).

\section{Authors' Contribution}

CG designed and conducted the morphological analysis and drafted the manuscript. CA contributed to molecular analysis. RB designed and conducted the molecular analysis and contributed writing the manuscript. All authors approved the final version of the manuscript.

\section{References}

André, E. (1883). Species des hyménoptères d'Europe et d'Algérie. Beaune, France: Edmond André, 919 p

Baroni Urbani, C. (1971). Catalogo delle specie di Formicidae d'Italia (Studi sulla mirmecofauna d'Italia X). Memorie della Società Entomologica Italiana, 50: 5-287.

Bernard, F. (1968). Faune de l'Europe et du bassin méditerranéen. 3. Les fourmis (Hymenoptera Formicidae) d'Europe occidentale et septentrionale. Paris, France: Masson, 411 p

Bernard, F. (1983). Les fourmis et leur milieu en France méditerranéenne. Paris, France: Lechevalier, 149 p

Casevitz-Weulersse, J. (1990). Etude systématique de la myrmécofaune corse (Hymenoptera, Formicidae). Bulletin du Museum National d'Histoire Naturelle, 12: 135-163. 
De Gaulle, J. (1908). Catalogue systématique et biologique des Hyménoptères de France, extrait de la Feuille des Jeunes Naturalistes, années 1906, 1907, 1908. Paris, France: Librairie Paul Klincksieck, $171 \mathrm{p}$

Edgar, R.C. (2004). MUSCLE: multiple sequence alignment with high accuracy and high throughput. Nucleic Acids Research, 32: 1792-1797. doi: 10.1093/nar/gkh340

Emery, C. (1908). Beiträge zur Monographie der Formiciden des paläarktischen Faunengebietes. (Hym.) (Fortsetzung.) III. Die mit Aphaenogaster verwandte Gattungengruppe. Deutsche Entomologische Zeitschrift, 1908: 305-338.

Finzi, B. (1930). Contributo allo studio degli Aphaenogaster paleartici (Formicidae-Myrmicinae). Bollettino della Società Entomologica Italiana, 62: 151-156.

Hebert, P.D.N., Penton, E.H., Burns, J.M., Janzen, D.H. \& Hallwachs, W. (2004). Ten species in one: DNA barcoding reveals cryptic species in the neotropical skipper butterfly Astraptes fulgerator. Proceedings of the National Academy of Sciences of the U.S.A., 101: 14812-14817. doi: 10.1073/ pnas.0406166101

Lanfear, R., Frandsen, P.B., Wright, A.M., Senfeld, T. \& Calcott, B. (2016). Partition Finder 2: new methods for selecting partitioned models of evolution for molecular and morphological phylogenetic analyses. Molecular Biology and Evolution, 34: 772-773. doi: 10.1093/molbev/msw260
Maddison, W.P., Maddison, D.R. (2017). Mesquite: a modular system for evolutionary analysis. Version $3.31 \mathrm{http}: / /$ mesquiteproject.org

Ronquist, F., Teslenko, M., van der Mark, P., Ayres, D.L., Darling, A., Hohna, S., Larget, B., Liu, L., Suchard, M.A. \& Huelsenbeck, J.P. (2012). MrBayes 3.2: efficient Bayesian phylogenetic inference and model choice across a large model space. Systematic Biology, 61: 539-542. doi: 10.1093/sysbio/ sys029

Salata, S. \& Borowiec, L. (2018). Redescription of Aphaenogaster muschtaidica Emery, 1908 with a key to gibbosa species group. Asian Myrmecology, 10: e010002. doi: 10.20362/ am. 010002

Santschi, F. (1925). Fourmis d'Espagne et autres espèces paléarctiques (Hymenoptera). EOS - Revista Española de Entomologia, 1: 339-360.

Schifani, E. \& Alicata, A. (2018). Exploring the myrmecofauna of Sicily: thirty-two new ant species recorded, including six new to Italy and many new aliens (Hymenoptera, Formicidae). Polish Journal of Entomology, 87: 323-348.

Schulz, A. (1994). Aphaenogaster graeca nova species (Hym: Formicidae) aus dem Olymp-Gebirge (Griechenland) und eine Gliederung der Gattung Aphaenogaster. Beitraege zur Entomologie, 44: 417-429. 